〈論 文〉

\title{
浮上性沪材を用いた下水の固液分離処理法の研究
}

\author{
毛 利 光 男* 丹羽 千 明*
}

\section{Study on the Solid-liquid Separation of Raw sewage Using Floating Media and Multiple Inlets}

\author{
Mitsuo MOURI* and Chiaki NIWA* \\ * Shimizu Corporation, Institute of Technology, 3-4-17, Etchujima, Koto-ku, Tokyo 135 Japan
}

\begin{abstract}
Characteristics and performance of solid-liquid separation of raw sewage using floating media and multiple inlets were studied in bench-scale and pilot-scale equipments.

The results are summarized as follows : Particles over $7 \mu \mathrm{m}$, representing approximately $80 \%$ of SS and $50 \%$ of BOD in raw sewage were efficiently removed. There was little difference in SS removal ratio (SSRR) between floating media and glass beads. The maximum SSRR and SS quantity removed per unit filter surface (SSR) was achieved using a particle size of $5.5 \mathrm{~mm}$ and a filtration rate of $150 \mathrm{~m} \cdot \mathrm{d}^{-1}$. Inlet switching to lower position of the filter column promised to prolong the filter run significantly and to increase total SS removed in filter. Using $5.5 \mathrm{~mm}$ filter particles, $80-89 \%$ of SS was removed, $38-42 \mathrm{~kg}$ of SS was removed per unit filter sectional area, and filter runs were 54-64 hours at a filtration rate of $150 \mathrm{~m} \cdot \mathrm{d}^{-1}$. The backwash-filtrate ratio was around $2 \%$. The space requirement of this system will be significantly smaller than the ordinary primary treatment system judging from the trial design of a practical scale plant.
\end{abstract}

Key words : solid-liquid separation, floating filter media, multiple filter column inlets, filtration, wastewater treatment

\section{1.はじめに}

社会環境の急激な変化により,下水道にも処理施設 の中小規模化に伴う処理方式の見直し，地価の高騰に より増加した用地取得費抑制のための施設の省面積化 などの早期に対処すべき問題が生じている。これらの 問題を解決するには，所要面積が小さく，簡素な維持 管理で済み，かつ処理効率が高くて建設費が低廉な処 理技術の開発が重要であり，現在，生物処理を中心と したリアクターの開発が急がれている1)。

一般に，生物による分解・除去作用は，溶解性また は，コロイド状物質に対しては，迅速に行われるが， 浮遊性の物質については緩やかであるといわれてい
る2)。したがって下水中の全有機物の60～80\%を占め る固形性有機物は, 生物分解を迅速に行うためには障 害となるものであり，バイオリアクターの処理速度を 高める上で, 流入下水中の浮遊性物質の 1 次処理によ る高度分離は，不可欠であると考えられる2)。 従来の沈殿分離法より高効率に下水中の浮遊性物質 を分離回収することができれば，後段のリアクターの 処理機能を高めるだけではなく, リアクター動力の大 幅な削減，分離回収した固形物の嫌気性処理によりメ タンガスとしてエネルギーを回収することができるな ど，処理システムのエネルギー効率を大幅に高めるこ とが可能になる。このため，沈殿分離に替わって下水 中の浮遊物質を迅速にかつ高効率に除去する新しい固 
液分離技術の開発が望まれている。

下水の高効率な固液分離処理には，汇過法が適して いると考えられるが，下水中の懸濁粒子は幅広い粒径 分布を有するため，従来の砂沪過法で下水を汇過する と，流入部の汇層は，粒径の大きな懸濁物により急速 に閉塞する。このため，汇過法で下水の固液分離を行 う場合は，沪層表部の閉塞防止のため沪材や原水供給 方法等に対する大幅な改善が必要となる。そこで，沪 層流入部の閉塞防止と内部沪過の促進による懸濁物捕 捉量の増加を図ることを目的として，従来の汇過材よ り粒子径が大きい発泡ポリスチレン粒子の人工沪材と 多段切換による原水供給方法の適用を主な特徵とする 新しい 1 次処理用固液分離法の研究を行った。

本研究において主に検討した項目は，懸濁物の高効 率除去に適した沪材径の選択，多段切り換え原水供給 方法の供給管設置間隔の決定，浮上性沪層の固液分離 性能，省面積化を実現するための高速沪過性，分離懸 濁物の沈降濃縮特性，および処理能力の安定性等であ る。さらに, これらの運転成績と処理特性から本処理 方式を実規模の 1 次処理に適用した場合の設置必要面 積と所要電力量を算定するケーススタディを行い，実 用に際しての省面積性と省エネルギー性についての検 討も行った。

\section{2. 本プロセスの概要と実験方法}

\section{1 浮上性沪過プロセスの概要}

本プロセスの概要を Fig.1 に示す。浮上性汇過槽に は表面が平滑な発泡ポリスチレン性沪材が充填され, また深さ方向に多段に原水供給管が設置されている。 原水は，原水ポンプによりまず最上段の供給管のみか ら汇層内へ供給管上部の穴から噴出，供給される。沪 材は浮上性のため，原水の逆流が生じない限り，供給 管上部の吐出口から供給管の中へは入らない。

原水中の SS 分は，汇層内を下向流で流下していく 過程で，捕捉・除去されていき，汇層下部より処理水

[Filtration Process]

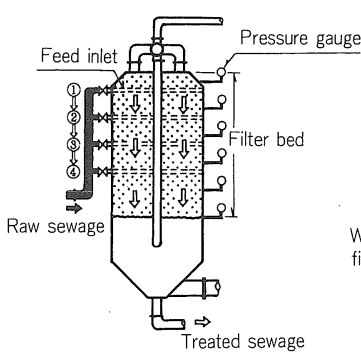

Fig. 1 Filtration and backwash process
が得られる。SS 分の捕捉により沪層の閉塞が進み，損 失水頭が設定值まで上昇するとレベルスイッチにより 自動的に原水供給を下段に切り換える。このように原 水供給を最上段の第 1 段から沪層の目詰りに応じ下方 の $2 ， 3 ， 4$ 段へ順次切り換えていく操作により疑似 的に沪層全体を有効に使った内部沪過の状態に近づけ ることができる。最下段供給時の損失水頭が設定值ま で上昇すると洗浄工程に入る。

浮上性沪材は，砂沪材に比べて水との比重差が小さ いため，水により沪層を膨張させて逆洗するという従 来法で洗浄しても所要エネルギーは小さくてすむ。し かし，本沪材の浮上するという特性を利用したエジエ クターによる洗浄方法の方がエネルギー的にさらに有 利である。そこで, 本沪材の洗浄はエジェクターで行 い，エジェクターの駆動水は，沪過槽内水，または処 理水を循環して用いる。エジェクターに送り込まれた 駆動水がエジェクター内を高速で通過する際に生じる 負圧により污濁汇材は，吸い込み管からエジェクター 内に吸引される。さらにエジェクター内部での剪断力 により付着したSS 分が剝離し，沪材粒子は洗浄され る。吐出管下端で洗浄粒子と剥離 SS 分は分離され, 洗 浄沪材は浮上して再び沪層を構成する。剥離 SS 分の 多くは沪過槽底部に沈降，分離される。この操作によ り，沪層上端から下端まで沪材をエジェクター内に順 次吸い込み，沪層全体を洗浄すると 1 回の洗浄工程が 終了する。

\section{2 実験装置の構成}

実証実験で用いたパイロットプラントのプロセスフ ローを Fig. 2 に示す。パイロットプラントは, 原水槽, 洗浄水槽, 浮上性沪過槽, 処理水槽, 処理水貯留槽, 各処理槽の接続配管，ポンプ，および制御系で構成さ

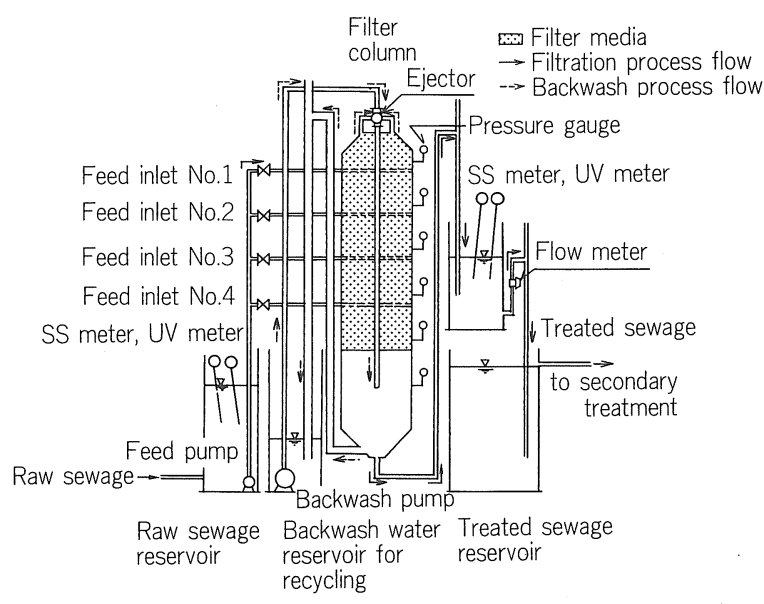

Fig. 2 Schematic of the pilot plant 
れている。沪過槽は, 断面積 $0.64 \mathrm{~m}^{2}(80 \mathrm{~cm} \times 80 \mathrm{~cm})$, 槽高 $4.5 \mathrm{~m}$ であり，沪材を $3 \mathrm{~m}$ 充填した。沪材は比重 0.03 発泡ポリスチレン粒子を用いた。汇層内に原水 供給管を $50 \mathrm{~cm}$ 間隔で 4 段に設置し各段の沪層内損失 水頭が設定值まで上昇すると下段の原水供給管へ切り 換えて汇過が綥続できるようにした。1段目供給時の 有効沪層厚 (使用供給管から下にある沪層厚) は $250 \mathrm{~cm}$ であり，4段目供給時の有効沪層厚は $100 \mathrm{~cm}$ である。 損失水頭が，その時の有効厚の沪層の浮力 $(1-\varepsilon) \cdot \mathrm{L}$ $(\varepsilon \fallingdotseq 0.4, \varepsilon$; 間隙率, $\mathrm{L}$; 沪層厚) より上昇すると浮上 性汇層に亀裂が入るため, 安全率 2 を見込み最も薄い 第 4 段の沪層厚 $(100 \mathrm{~cm})$ より，約 $30 \mathrm{~cm}$ を損失水頭設 定値とした。原水供給の下段への切り換えの制御は, 沪過槽の側壁に設置してあるマノメー夕管内のレベル スイッチにより行い，原水供給段の沪層の損失水頭上 昇を感知すると下段供給管の電磁弁を開き，前の供給 管の電磁弁を閉じるようにした。第 4 段の汇層の損失 水頭が設定值に達するとすべての段の供給管の電磁弁 は閉じ，洗浄工程に入る。

沪過槽の上部には, 吸込·排出径が75mm クターが 2 カ所に設置されている。エジェクターの駆 動水圧を $2 \mathrm{~kg} \cdot \mathrm{cm}^{-2}$ とし， $3 \mathrm{~m}$ の沪層を一巡吸い込 むのに要する時間を10分間に設定した。沪材の洗浄は， 2 回の洗浄工程により行い，1 回目の洗浄には沪過槽 内水，2 回目の洗浄には沪過処理水を使用した。

沪材粒子径の選定等の予備実験は，小型沪過装置を 用いて行った。沪過槽は，断面積 $0.49 \mathrm{~m}^{2}(70 \mathrm{~cm} \times 70$ $\mathrm{cm}$ ), 槽高 $2.5 \mathrm{~m}$ ，沪層厚0.8 1.5m であり，原水供給 管は，1段のみ設置されている。小型である以外基本 的なプロセスは,Fig. 2 の実証プラントと同じである。

\section{3 実験方法と運転条件}

\subsection{1 小型沪過装置実験}

浮上性沪材の径による SS 除去率と捕捉量の違いを 沪速 $150 \mathrm{~m} \cdot \mathrm{d}^{-1}$ の定量沪過の条件下で検討した。実験 は，沪材径 $0.8 ， 2.5 ， 5.5 \mathrm{~mm}$ の 3 種類で行った。ポリ スチレン粒子を発泡させ球形で均一な径を安定して作 成できる最大の平均径はほほ $6 \mathrm{~mm}$ のため, $5.5 \mathrm{~mm}$ は発泡ポリスチレン沪材としては, ほぼ最大径となる。 また，無機系汇材との比較を行うため, 5.0, 7.0 mm の ガラス沪材を円筒カラム $(150 \mathrm{~cm}$ 高, $10 \mathrm{~cm}$ 径) に充填 し，別途 $200 \mathrm{~m} \cdot \mathrm{d}^{-1}$ の定量沪過実験を行った。比較実験 に用いた沪材の仕様を Table I に示す。

原水供給管の設置間隔を決めるため，沪過槽の側壁 に設置してあるマノメーター管により，懸濁物捕捉に 伴う汇層内の損失水頭分布を求污，汇層内への SS 分 浸透距離を把握した。沪過速度が高い方が汇層内の浸 透距離も長くなると考えられるため, $200 \mathrm{~m} ・ \mathrm{~d}^{-1}$ の沪過
Table 1 Materials of filter media and their properties

\begin{tabular}{|c|c|c|c|}
\hline Material & $\begin{array}{c}\text { Mean } \\
\text { diameter }\end{array}$ & $\begin{array}{c}\text { Uniformity } \\
\text { coefficient }\end{array}$ & $\begin{array}{c}\text { Porosity } \\
\text { of clean bed }\end{array}$ \\
\hline expanded polystyrene & $0.8 \mathrm{~mm}$ & 1.16 & 0.35 \\
\hline expanded polystyrene & $2.5 \mathrm{~mm}$ & 1.16 & 0.35 \\
\hline expanded polystyrene & $5.5 \mathrm{~mm}$ & 1.15 & 0.36 \\
\hline glass & $5.0 \mathrm{~mm}$ & 1.10 & 0.36 \\
\hline glass & $7.0 \mathrm{~mm}$ & 1.11 & 0.38 \\
\hline
\end{tabular}

速度で実験を行った。

\subsection{2 パイロットプラント実験}

Fig. 2 に示すパイロットプラントを用いて，1988年 8 月から1990年 3 月にわたり長期連続実証実験を行っ た。小型実験の結果より，パイロットプラント実験は， $5.5 \mathrm{~mm}$ の浮上性沪材を用いて行った。

定量沪過実験は，主に $75,150,220 \mathrm{~m} \cdot \mathrm{d}^{-1}$ の 3 段階の 沪過速度で行い，変動汇過実験は，75～ $220 \mathrm{~m} \cdot \mathrm{d}^{-1}$ の範 囲で段階的に汇過速度を変化させて行った。

エジェクター洗浄が浮上性沪材の縮小に与える影響 を検討するため,長期連続運転中の沪材をさらに244時 間（洗浄時間としては 5.5 年間分に相当）にわたり洗浄 し，沪材径の変化を測定した。

\section{3 .3 測定方法}

原水抒よび汇過処理水の SS 濃度（下水試験法によ る分析值) と SS 計（電気化学計器侏製，SSD-10）の 計測指示值との相関が十分に高いことが統計的に確認 できたため，連続沪過実験の SS 濃度の測定には，SS 計を使用した。計測指示值の校正は，2 2 力月毎に 50個以上の分析值を用いて行った。データの相関性を 寄与率 $\left(r^{2}\right)$ で表現すると, 原水計測の場合は $r^{2}=$

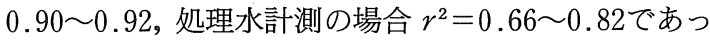
た。

連続実験中の原水と処理水の SS の計測は 5 分毎に 行い, 計測指示值を回帰式により SS 濃度に換算し,こ のデー夕を用いて連続実験時の SS 除去率，単位沪過 面積当たりのSS 捕捉量等を求めた。

沪過速度は, 処理水槽に設置してある電磁流量計(横 河電機(侏製，CYM-10）の流量計測值から求めた。損 失水頭の計測は，沪過槽の側壁に設置してある圧力計 （長野計器侏製，KH21）とマノメーター管の両方を用 いた。沪過速度と損失水頭も5 分毎に計測を行った。

\section{4 実験原水}

小型沪過装置の多くの実験およびパイロットプラン トのすべての実験の原水には，茨城県湖北流域下水処 理場のスクリーン処理水を用いた。その主な性状を

Table 2 に示す。 
小型沪過装置の一部の実験は，住宅都市整備公団ひ ばりケ丘団地污水処理場の生活排水を用いて行った。 原水 $\mathrm{SS}$ 濃度は， $70 ２ 40 \mathrm{mg} \cdot l^{-1}$ であり，その平均值 は, $126 \mathrm{mg} \cdot l^{-1}$ であった。

\section{3．小型沪過装置実験の結果と考察}

\subsection{SS 除去性能による沪材径の選定}

浮上性沪材径の選定は, 有効沪層厚が $100 \mathrm{~cm}$, 沪過速 度が $150 \mathrm{~m} \cdot \mathrm{d}^{-1}$ の定量沪過条件下の SS 除去率と単位 沪過面積当りの SS 捕捉量により行った。 $0.8 \mathrm{~mm}$ 粒子 使用時は，平均 SS 除去率は最も高く87～90\%であっ たが，汇層の閉塞も早く汇過継続時間が短いため，単 位沪過面積当りの SS 捕捉量は 3 種類の中で最も小さ く0.3〜0.5 $\mathrm{kg} \cdot \mathrm{m}^{-2}$ であった。また，原水 SS 分の沪層 への分散が平均的に行われず，水みちを形成し，破過 が発生する場合が多かった。

$2.5 \mathrm{~mm} ， 5.5 \mathrm{~mm}$ 粒子の SS 除去率は両者とも 82〜 85\%と同程度であるが，沪過継続時間の違いによ り，単位沪過面積当たりの SS 捕捉量には大きな差が できた。2.5mm 径は，1〜2.5kg・m-2であり, $5.5 \mathrm{~mm}$ 径は7.5〜 $12.5 \mathrm{~kg} \cdot \mathrm{m}^{-2}$ であった。浮上性沪材の場合は, 0.8 ～ $5.5 \mathrm{~mm}$ の範囲では汇材径が大きくなるほど SS 捕捉量は増大するが, SS 除去率はわずかしか低下しな いことが認められた。

これより,本沪過法には $5.5 \mathrm{~mm}$ 径の汇材の使用が最 適と考えられるため，パイロットプラント実験には， $5.5 \mathrm{~mm}$ 径を使用した。

\section{2 浮上性沪材と無機性沪材との比較}

発泡ポリスチレン沪材の $\xi$ 電位は，無機性沪材と異 なり正に帯電している゙๋た, 本沪材による水中の微 細な懸濁粒子の捕捉能力が，無機性沪材と異なること も予想された。このため，無機性汇材としてガラス玉 を選び， $5.5 \mathrm{~mm}$ 径の浮上性汇材と $5.0 \mathrm{~mm}$ 径のガラス 沪材の微細懸濁物の除去性の比較を円筒カラムを用い て行った。微細粒子の除去を評価するため $74 \mu \mathrm{m}$ の金 網篩いを通過した原水を用いて, 有効汇層厚 $100 \mathrm{~cm}$, 沪 過速度 $200 \mathrm{~m} \cdot \mathrm{d}^{-1}$ の条件で実験した。また，汇材が5.5 $\mathrm{mm}$ 径より大きい場合の SS 除去性を評価するため, $7.0 \mathrm{~mm}$ 径のガラス沪材による沪過実験も併せて行っ た。結果を Fig. 3 に示す。

Table 2 Properties of raw and treated sewage

\begin{tabular}{|c|c|c|}
\hline Item & Raw sewage & Treated sewage \\
\hline SS $\quad\left(m g \cdot 1^{-1}\right)$ & $70 \sim 507$ (av. 190) & $14 \sim 52$ (av.29) \\
\hline $\mathrm{T}-\mathrm{BOD}_{5}\left(\mathrm{mg} \cdot \mathrm{I}^{-1}\right)$ & $70 \sim 244$ (av. 186) & 48 135 (av. 84) \\
\hline $\mathrm{S}-\mathrm{BOD}_{5}\left(\mathrm{mg} \cdot \mathrm{I}^{-1}\right)$ & $27 \sim 82($ av. 54$)$ & $23 \sim 69$ (av.42) \\
\hline
\end{tabular}

$5.5 \mathrm{~mm}$ 径の浮上性沪材と $5.0 \mathrm{~mm}$ 径のガラス汇材の $74 \mu \mathrm{m}$ 以下の SS 分の除去パターンはほぼ同じであ り，原水供給点から 10～20cm の沪層部分で SS の $60 \%$ 程度が除去されることがわかった。下水中の $74 \mu \mathrm{m}$ 以 下の懸濁物の分離に関して， $\xi$ 電位の影響は認められ ず，浮上性沪材とガラス沪材との間に大きな違いがな いことがわかった。これより，沪材径が $5.5 \mathrm{~mm}$ より大 きくなった場合の SS 除去率は，浮上性沪材の代わり にガラス沪材を用いて推定できることがわかった。

上記と同じ条件でガラス沪材による $5.0 \mathrm{~mm}$ 径と 7.0 $\mathrm{mm}$ 径の比較実験を行った結果, Fig.3に示すように, $7.0 \mathrm{~mm}$ 径のガラス沪材の SS 除去率は, 同じ沪層厚の $5.0 \mathrm{~mm}$ 径よりかなり低下することがわかった。

3.10 結果と併せると, 高除去率と懸濁物捕捉量の増 大を同時に目指す本沪過法に適した沪材径は $5.5 \mathrm{~mm}$ 程度であると考えられる。

\section{3 原水供給管の設置間隔の選定}

$5.5 \mathrm{~mm}$ 径の浮上性沪層内の SS 分浸透距離を把握 するため，原水供給点から沪過方向に $5 \mathrm{~cm} ， 10 \mathrm{~cm}$ ， $18 \mathrm{~cm}$ ，および $50 \mathrm{~cm}$ の地点にあるマノメータを用いて 単位面積当りの SS 捕捉量と各点の損失水頭上昇量の 関係を求めた。この小実験では，損失水頭上昇量が 60〜 70 cm になると処理水質の悪化が始まったため， その時点で沪過を終了した。

Fig. 4 に示すように, $18 \mathrm{~cm}$ 以上まで SS 分が浸透し ている場合と $10 \mathrm{~cm}$ までに SS 分の多くが捕捉されて いる場合があるが，いずれの場合も $50 \mathrm{~cm}$ まではさほ ど浸透しないことがわかった。これより，パイロット プラント実験装置の原水供給管の間隔を $50 \mathrm{~cm}$ に設定 した。また，損失水頭は，単位汇過面積当りの SS 捕捉 量が 6 〜 $\mathrm{kg} \cdot \mathrm{m}^{-2}$ から急激に上昇することもわかっ た。

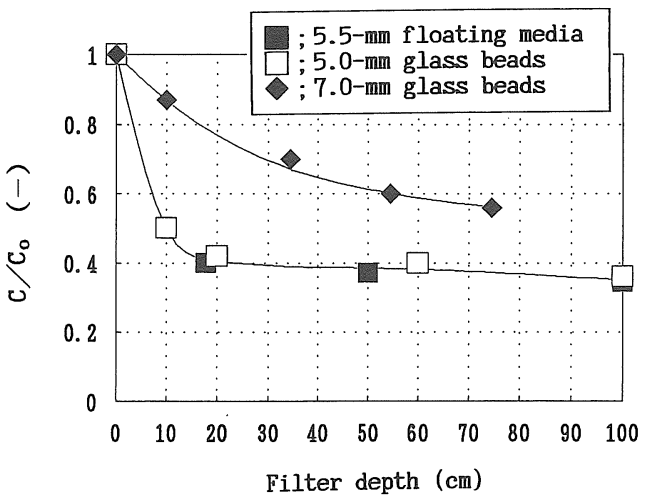

Fig. 3 Comparison of filter performance between floating media and glass beads 


\section{4 . パイロットプラント実験の結果と考察}

\section{1 流入原水の特性}

原水中の SS おろび有機物の粒度分布特性の代表例 を Fig. 5 に示す。原水と処理水の汇紙による篩い分け は，沪紙上で沪涬沪過が起こらないように，目詰まり に注意して行った。原水 SS の約 $80 \%$ は $7 \mu \mathrm{m}$ (東洋汇 紙 No. 5A）以上の懸濁粒子であること，T-COD，T -BOD，Kj-N は $7 \mu \mathrm{m}$ 以下の懸濁粒子と溶解成分の 全体に占める割合が高いことがわかった。

\section{2 沪過処理水の特性}

沪過処理水の主な性状を Table 2 に示す。実験を 行った 75〜 220 m•d $\mathrm{d}^{-1}$ の沪過速度の範囲では, 汇過処理 水の SS 粒度分布特性に大きな違いはなかった。150 $\mathrm{m} \cdot \mathrm{d}^{-1}$ の定量沪過時の分布特性の例を Fig. 6 亿示す。 本法の汇過により $7 \mu \mathrm{m}$ 以上の懸濁粒子のほとんど が除去されることが認められた。このため $7 \mu \mathrm{m}$ 以上 の懸濁粒子が占める原水中の SS の約 $80 \%$ 分，T-COD の約 $40 \%$ 分およびT-BOD の約50\%分は本沪過によ りほとんど除去される。BOD や COD 分のように溶解 成分の比率が高いものは, SS 並みの高い除去率は得ら れにくいことがわかった。
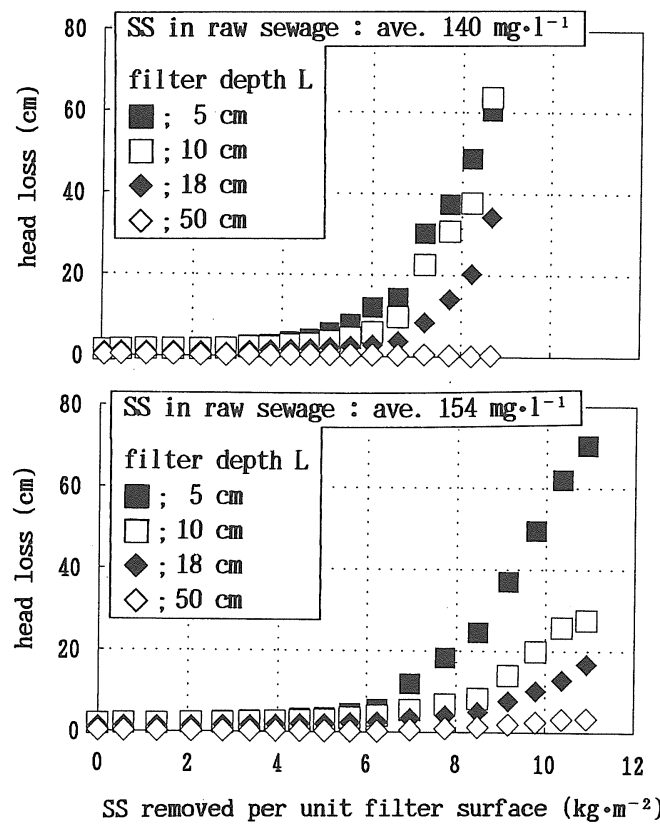

Fig. 4 Relationship between SS removed per unit filter surface and head losses head loss $=\mathrm{h}_{\mathrm{fL}}-\mathrm{h}_{\mathrm{fo}}$

$\mathrm{h}_{\mathrm{fL}}$ : head loss in filter depth $\mathrm{L}$, below the feed inlet

$h_{\text {fo }}$ : head loss through the clean bed

\section{3 多段切り換え定量沪過実験の結果と考察}

\subsection{1 多段切り換え定量沪過の性能}

Fig. 7 に多段切り換え定量沪過の沪過時間と SS 除 去率, SS 捕捉量, および損失水頭等の関係の一例を示 す。SS 除去率が $80 \%$ 以上であること，沪層が懸濁物に より閉塞すると原水供給が順次下段の沪層へ移り沪過 継続時間が大幅に延長されること，およびこれに伴い SS 捕捉量も大幅に増大すること等がわかる。多段切り 換え供給により, 全沪層の SS 捕捉量と汇過時間は, 従 来の 1 段のみの供給の場合に比べて各々 $3 \sim 4$ 倍に達 する。また，洗浄水量比も $1.7 \sim 2.6 \%$ と $3 \%$ 末満であ る。定量汇過時の性能を汇過速度ごとにまとめて Table 3 に示す。150 $220 \mathrm{~m} ・ \mathrm{~d}^{-1}$ の汇過速度で確実に 1 日以上連続して沪過を継続できること，最初沈殿池の 水面積負荷と比較すると大幅な省面積化が可能である こと等がわかった。

\subsection{2 原水濃度の SS 除去性能への影響}

Fig. 7 より，原水濃度が大きく変動しても SS 除去 率はおおむね安定していることが認められる。原水 SS 濃度の変動係数（標準偏差と平均值との比）と平均 SS 除去率の関係を調べたところ，原水濃度が変動係数で 0.4 まで変動しても，汇過の SS 除去率は安定している ことがわかった。

Fig. 8 亿原水平均 SS 濃度と沪過継続時間の関係を 示す。原水の平均 SS 濃度が高いほど, 汇過継続時間が

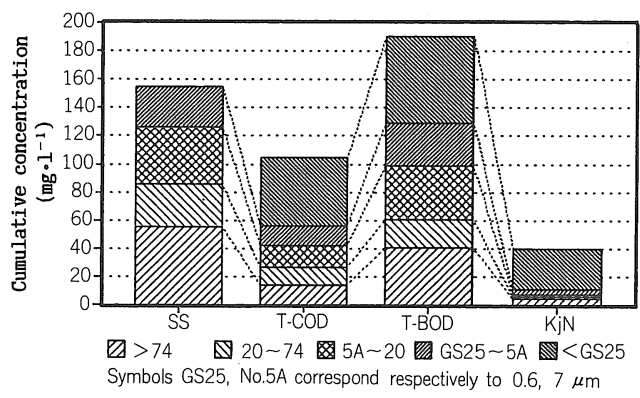

Fig. 5 Particle size distributions of raw sewage

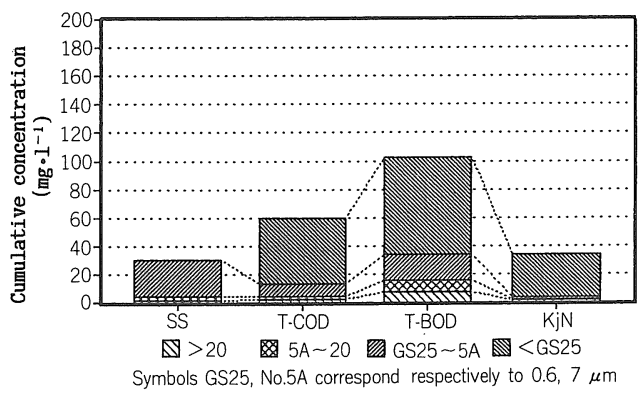

Fig. 6 Particle size distributions of treated sewage 
短くなる傾向が認められた。

\subsection{3 沪過速度と SS 除去性能の関係}

Fig.9 に沪過速度と SS 除去率および全汇層（４段） の総 SS 捕捉量との関係を示す。総 SS 捕捉量は，150 $\mathrm{m} \cdot \mathrm{d}^{-1}$ の時が最大であり， $75 \mathrm{~m} \cdot \mathrm{d}^{-1}$ と $220 \mathrm{~m} \cdot \mathrm{d}^{-1}$ の時は おおむね同じであった。SS 除去率は, $150 \mathrm{~m} ・ \mathrm{~d}^{-1}$ の時が 最大であり, $220 \mathrm{~m} \cdot \mathrm{d}^{-1}$ の時は,それより 3 〜 $6 \%$ 低下， $75 \mathrm{~m} \cdot \mathrm{d}^{-1}$ の時も数\%程度低下した。高速汇過時は汇層 内に抑留された SS 分の一部が流出しやすくなるため 除去率が低下するものと考えられる。また，低速沪過 時は SS 分の浸透距離が短いため，有効な内部沪過を

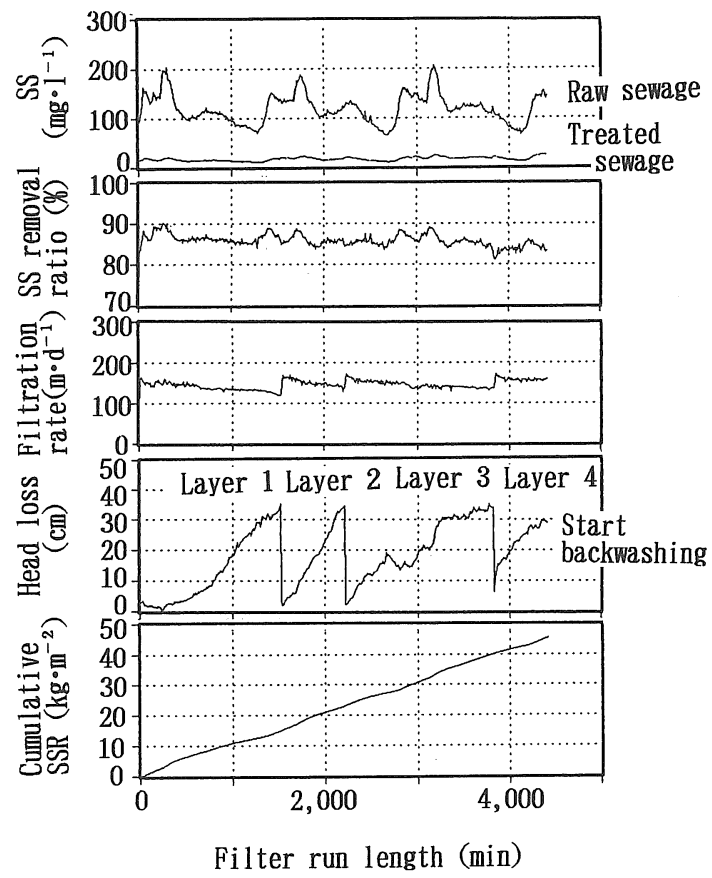

Fig. 7 Filter performance of constant-rate filtration at $150 \mathrm{~m} \cdot \mathrm{d}^{-1}$

SSR : SS removed per unit filter surface
達成できず総捕捉量と SS 除去率が低下するものと推 定される。

\subsection{4 多段切り換え供給による下部沪層への影響}

Fig. 10 に各供給段と SS 捕捉量の関係を示す。単位 面積当りの SS 捕捉量は第 1 段，第 2 段はほほ同量の 捕捉性能を有する。しかし，下段の沪層になるほど上 段から漏出した SS 分の影響を受けるため, SS 捕捉量 は，第 3 段，第 4 段と徐々に減少すること，また捕捉 量もばらつきやすくなることがわかった。

\section{4 多段切り換え変動沪過実験の結果と考察}

原水供給ポンプをインバーターにより汇過速度が 75〜 $220 \mathrm{~m} \cdot \mathrm{d}^{-1}$ の範囲で段階的に増減するように制御 して多段切り換え変動沪過実験を行った。Fig.11に結 果の一例を示す。 SS 除去率は原水 SS 濃度と沪過速度 が変動してもおおむね $80 \%$ 前後で一定であること，各 段の汇過継続時間は原水 SS 濃度と沪過速度の変動の 影響を受けてかなりばらつくことがわかつた。変動沪 過時の沪過性能を Table 3 に示す。

Table 3 において変動沪過と定量沪過の比較を行 う。変動沪過の場合，沪過速度と原水濃度のピークが 重なり合う場合も多いため，汇過継続時間や SS 捕捉 量等の沪過性能と洗浄水量比は，定量沪過に比べてば

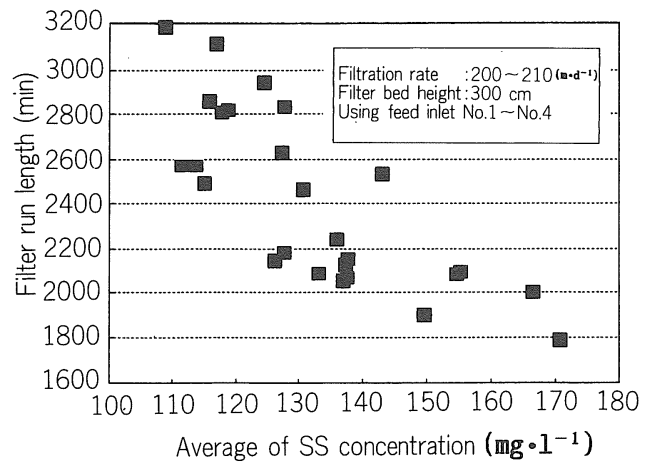

Fig. 8 Effect of SS concentration on filter run length

Table 3 Comparison of CRF and VRF filter performances

\begin{tabular}{|c|c|c|c|c|c|}
\hline & & \multicolumn{3}{|c|}{$\mathrm{CRF}$} & \multirow{2}{*}{$\begin{array}{r}\mathrm{VR} \mathrm{F}^{*} \\
\text { av. } 135 \mathrm{~m} \cdot \mathrm{d}^{-1}\end{array}$} \\
\hline & & $75 m \cdot d^{-1}$ & $150 m \cdot d^{-1}$ & $220 m \cdot d^{-1}$ & \\
\hline Filter run length & $(\mathrm{h})$ & $76 \sim 96$ & $54 \sim 64$ & $30 \sim 42$ & $28 \sim 49$ \\
\hline SS removal ratio & (\%) & $81 \sim 86$ & $85 \sim 89$ & $78 \sim 83$ & $78 \sim 84$ \\
\hline Total SS removed in filter & $\left(\mathrm{kg} \cdot \mathrm{m}^{-2}\right)$ & $33 \sim 39$ & $38 \sim 42$ & $33 \sim 37$ & $26 \sim 37$ \\
\hline Backwash volume ratio & $(\%)$ & $2.0 \sim 2.6$ & $1.7 \sim 2.0$ & $2.0 \sim 2.6$ & $2.3 \sim 4.0$ \\
\hline
\end{tabular}

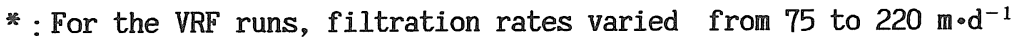
CRF : constant-rate filtration, VRF : variable-rate filtration 


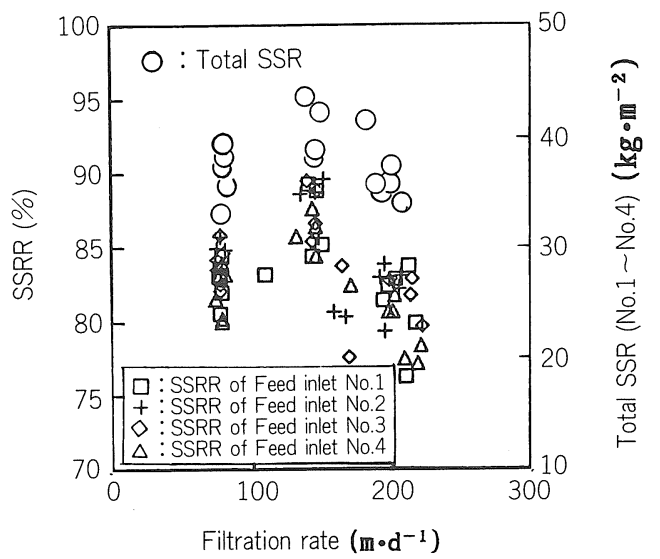

Fig. 9 Effect of filtration rate on filter performance SSRR: SS removal ratio

SSR : SS removed per unit filter surface

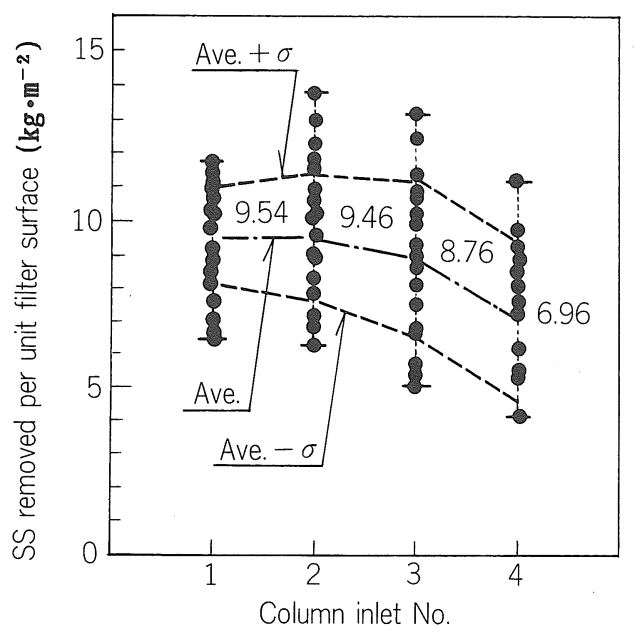

Fig. 10 Effect of multiple filter column inlets on SSR

らつきが大きく，かつ多少低下することがわかる。し かし，沪過速度が変動しても，本沪過法が目標とする $80 \%$ 以上の SS 除去率，1 日以上の沪過継続時間およ び $5 \%$ 以下の洗浄水量比を十分達成できることがわ かった。

\section{5 浮上性沪材の縮小}

長期連続実験に使用する沪材の選定の一環として， 発泡倍率の異なる 2 種類の $5.5 \mathrm{~mm}$ 径浮上性沪材の初 期縮小の状況を調べた。発泡倍率の大きな汇材は，約 30日の運転で沪層厚が初期值の $82 \%$ まで減少するこ と, 発泡倍率の小さな沪材は, 約40日間の運転で初期 值の $91 \%$ まで減少するがそれ以降の減少は小さいこと が判明した。これより，長期連続汇過実験には，後者 の汇材を使用した。
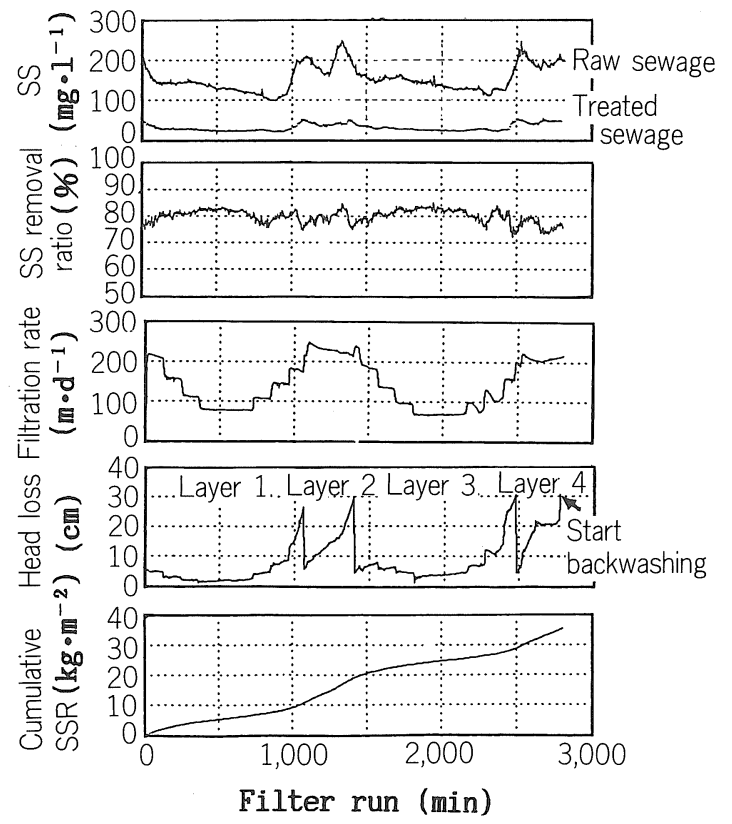

Fig. 11 Filter performance of variable-rate filtration SSR : SS removed per unit filter surface

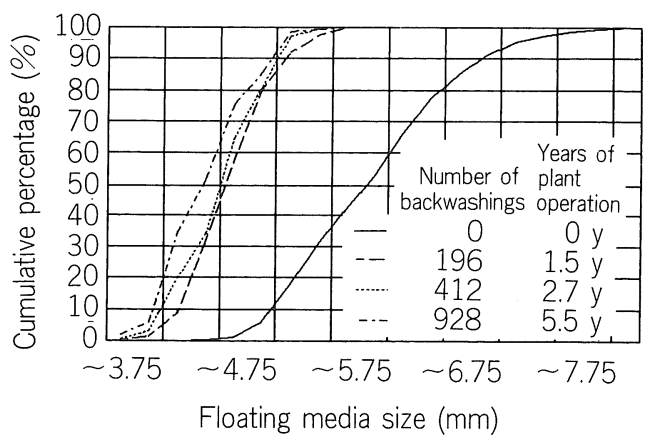

Fig. 12 Effect of ejector backwashing on long-term changes in filter medium size

汇材径が $5.5 \mathrm{~mm}$ と大きいため, 懸濁物捕捉に伴う損 失水頭の上昇量は, Fig.7 に示すように小さい。これ より，沪材の縮小は，エジェクター洗浄工程で受ける 剪断力等の力によるものと考えられる。そこで,エジェ クター洗浄による沪材径の長期的な縮小の検討を行っ た。エジェクター洗浄回数（または沪過年数）と沪材 径縮小の関係を Fig. 12 に示す。洗浄回数196回の沪材 径は連続運転 1 年半後の值であり，かつエジェクター 連続洗浄試験の初期值である。412回と928回の值は連 続洗浄72時間後と 244 時間後の沪材径を示す。（1 回の 洗浄時間を 20 分とし通常運転時の洗浄回数に換算し た。)さらに，連続洗浄試験の結果を $180 \mathrm{~m} \cdot \mathrm{d}^{-1}$ 程度の沪 
過速度で運転した場合の洗浄頻度值（2 日に 1 回）を 用いて汇過運転相当年数に換算し図中に示した。Fig。 12 により沪材径は1.5年間の運転で初期值の約 $80 \%$ （50\%粒径で比較）まで縮小するがその後は，5.5年分 に相当する洗浄試験後も初期值の約 $76 \%$ とさほど縮小 しないことが判明した。

汇材が縮小することにより，汇過性能が変わること が予想される。汇材縮小による汇過性能への影響を把 握するため，沪材の初期縮小が終了したと考えられた 1989年 1 月とその半年後の1989年 6 月の沪過性能（除 去率，捕捉 SS 量等)の比較を行ったが，統計的に有意 な差はないことがわかった。

また, 1.5 年間の連続運転期間中に浮上性沪材のマッ
ドボールの形成は，観察されなかった。

\section{6 本プロセスの懸濁物の物質収支}

$200 \mathrm{~m} \cdot \mathrm{d}^{-1}$ の定量沪過の場合の多段 (4 段) 切り換え 定量高速沪過時の SS 物質収支を一連の沪過実験結果 の平均值から試算し，Fig.13 に示す。なお，図中の諸 数值は単位沪過面積 $\left(1 \mathrm{~m}^{2}\right)$ 当りの換算値である。沪過 工程では前回工程の残存 $\mathrm{SS}$ 分 $12 \mathrm{~kg} \cdot \mathrm{m}^{-2}$ と沪過によ る捕捉 $\mathrm{SS}$ 分 $36 \mathrm{~kg} \cdot \mathrm{m}^{-2}$ の合計 $48 \mathrm{~kg} \cdot \mathrm{m}^{-2}$ が沪層内の全 $\mathrm{SS}$ 量になる。洗浄工程によりその $75 \%$ の $36 \mathrm{~kg} \cdot \mathrm{m}^{-2}$ の $\mathrm{SS}$ 分が系外へ排出， $25 \%$ の $12 \mathrm{~kg} ・ \mathrm{~m}^{-2}$ の SS 分が系内 に残存する。また，洗浄水量比は $2 \%$ 程度である。

\section{7 洗浄排水と濃縮污泥の性状}

1 度の洗浄工程の洗浄排水は，2 回排出される。 1
【Filtration Process】

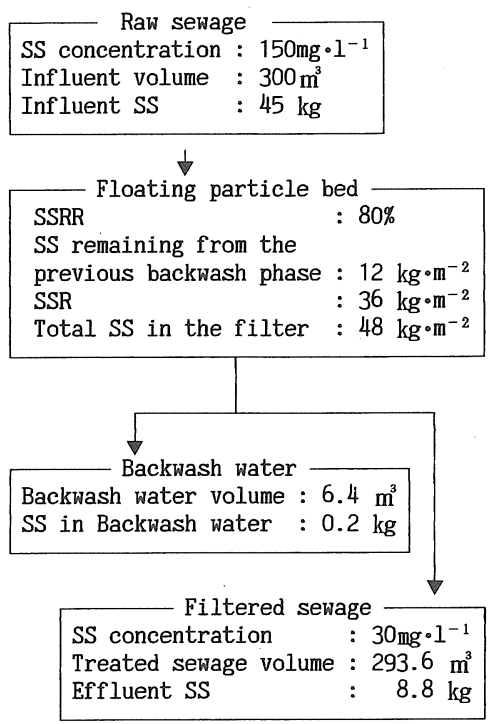

【Backwash Process】

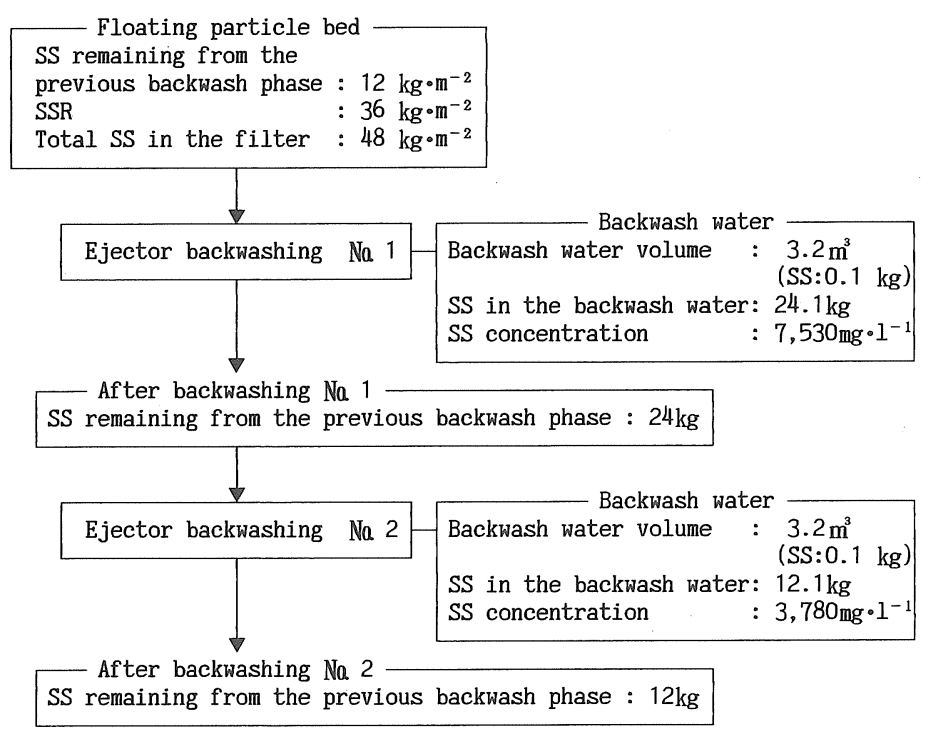

(a) Filter column area : $1 \mathrm{~m}^{2}$

(c) Filtration rate : $200 \mathrm{~m} \cdot \mathrm{d}^{-1}$

(b) Filter bed height : $3 \mathrm{~m}$

(d) Filter run length : $36 \mathrm{~h}$

Fig. 13 Material balance of SS

Table 4 Properties of backwash water and thickened sludge

\begin{tabular}{|c|c|c|c|c|c|}
\hline & $\begin{array}{l}\text { Backwash } \\
\text { water No. } 1\end{array}$ & $\begin{array}{l}\text { Thickened } \\
\text { sludge } \\
\text { of backwash } \\
\text { water No.1 }\end{array}$ & $\begin{array}{l}\text { Backwash } \\
\text { water No.2 }\end{array}$ & $\begin{array}{l}\text { Composite } \\
\text { sample of } \\
\text { backwash water } \\
\text { No. } 1 \text { and No.2 }\end{array}$ & $\begin{array}{l}\text { Thickened } \\
\text { sludge of } \\
\text { composite } \\
\text { sample }\end{array}$ \\
\hline SS $\quad\left(m g \cdot l^{-1}\right)$ & 6,640 & 34,770 & 3,170 & 4,790 & 25,850 \\
\hline TS $\quad\left(m g \cdot l^{-1}\right)$ & 7,350 & 35,250 & 3,590 & 5,580 & 26,840 \\
\hline VS $\quad\left(\mathrm{mg} \cdot \mathrm{l}^{-1}\right)$ & 5,540 & 27,460 & 2,630 & 4,190 & 21,890 \\
\hline $\mathrm{COD} \quad\left(\mathrm{mg} \cdot \mathrm{I}^{-1}\right)$ & 7,510 & 43,940 & 3,585 & 5,800 & 34,560 \\
\hline $\mathrm{kj}-\mathrm{N}\left(\mathrm{mg} \cdot \mathrm{l}^{-1}\right)$ & 290 & 1,128 & 154 & 266 & 1,080 \\
\hline $\mathrm{T}-\mathrm{P} \quad\left(\mathrm{mg} \cdot \mathrm{l}^{-1}\right)$ & 38.8 & 189.5 & 24.5 & 34.8 & 168.2 \\
\hline
\end{tabular}


回目の洗浄排水および 1 回目と 2 回目の洗浄排水を等 分に混合したものを 24 時間静置，濃縮した。洗浄排水 は 2 時間の静置で初期体積の $22 \% ， 24$ 時間で $19 \%$ 程度 まで濃縮された。洗浄および濃縮污泥の性状例を

Table 4 に示す。

\section{5. 試設計による検討}

実プラントとして適用した場合の問題点の検討，所 要面積および所要電力量等の算定を目的として試設計 による検討を行った。 $5,000 \mathrm{~m}^{3} ・ \mathrm{~d}^{-1}$ と $50,000 \mathrm{~m}^{3} \cdot \mathrm{d}^{-1}$ の 規模の試設計を以下に示す前提条件を用いて行った。 【前提条件】

（1）原水 $\mathrm{SS}$ 濃度 $: 200 \mathrm{mg} \cdot l^{-1}$

(2) SS 除去率 : $75 \sim 85 \%$

（3）汇過方式：4段切り換え汇過，下向流式

（4）沪過速度 : 平均 $150 \mathrm{~m} \cdot \mathrm{d}^{-1}$, 最大 $230 \mathrm{~m} \cdot \mathrm{d}^{-1}$

（5）沪材洗浄頻度：1日に 1 回

Fig.14に計画プラントの平面図と立面図を示す。さ らに規模が大きな場合も，大きくした各ユニットをさ らに複数，並列に設置することによって対応できると 考えている。

所要電力量は, $5,000 \mathrm{~m}^{3} \cdot \mathrm{d}^{-1}$ 規模で $0.056 \sim 0.078$ $\mathrm{kwh} \cdot \mathrm{m}^{-3}$ である。沪過工程の所要面積は $5,000 \mathrm{~m}^{3} \cdot \mathrm{d}^{-1}$ で約 $90 \mathrm{~m}^{2}, 50,000 \mathrm{~m}^{3} \cdot \mathrm{d}^{-1}$ で約 $627 \mathrm{~m}^{2}$ である。最初沈殿 池の所要面積の35～50\%であり，かなり省面積化され ると考えられる。

\section{6. と め}

浮上性汇材と多段切り換え供給法を用いた下水の迅 速な固液分離法について検討し，以下の結果が得られ た。

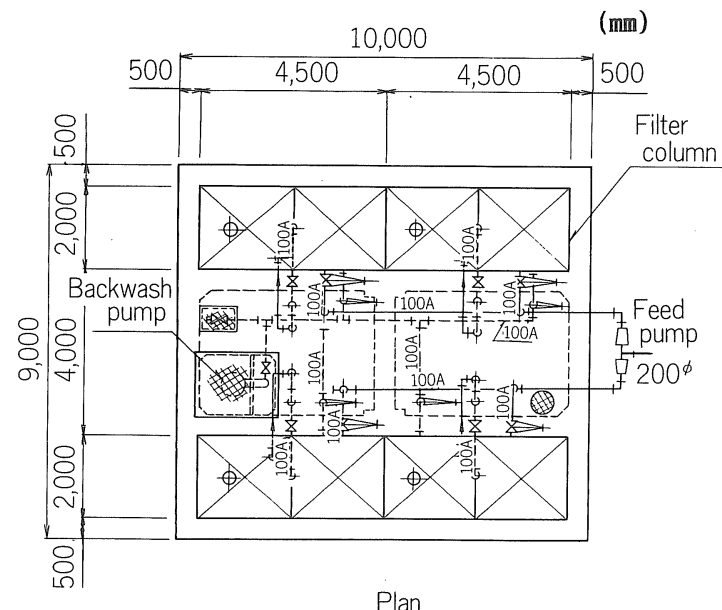

1) SS 除去率やSS 捕捉量の沪過性能から判断し て, $5.5 \mathrm{~mm}$ 径の汇材が本沪過法に適切であることがわ かった。

2）スクリーン通過後の下水を直接汇過し，下水中 の $7 \mu \mathrm{m}$ 以上の懸濁粒子のほとんどを除去できるこ とがわかった。このため, SS 分については $80 \%$ 以上の 高い除去率が得られる。BOD や COD は溶解成分の比 率が高いため, SS 並みの高い除去率を得ることは難し いが，40～50\%の除去が可能である。

3 ）下水中の $74 \mu \mathrm{m}$ 以下の懸濁物の分離に関して, 浮上性沪材とガラス沪材との間に大きな除去性の違い はなかった。このため,これらの沪材の $\xi$ 電位の違い による SS 除去性の差は，ほとんどないと考えられる。

4 ) 多段 (4段) 切り換え供給により，汇過継続時 間 (气洗浄間隔) と SS 捕捉量を従来の 1 段のみの供給 に比べて $3 〜 4$ 倍まで増加させることができた。沪過 継続時間は30時間以上，洗浄水量比は $2 \sim 4 \%$ あっ た。

5 ） $220 \mathrm{~m} \cdot \mathrm{d}^{-1}$ 程度までの高速沪過が可能なことを 確認した。 SS 除去率と SS 捕捉量は, $150 \mathrm{~m} \cdot \mathrm{d}^{-1}$ の沪過 速度の時に最大になることがわかった。

6 ）原水供給段の間隔を $50 \mathrm{~cm}$ に設定した場合，沪 過段の切り換えによる下段沪層への懸濁物漏出の影響 は第 3 段〜第 4 段から現れ, SS 捕捉量を低下させるこ とがわかった。

7 ）沪材径は, 1.5年間の運転で初期値の約 $80 \%$ まで 縮小するが,その後は, 5.5 年相当後も初期值の $76 \%$ と, さほど縮小が進まないことがわかった。また，1.5年間 の連続運転期間中，浮上性沪材のマッドボールの形成 は観察されなかった。

8 ) $5,000 \mathrm{~m}^{3} \cdot \mathrm{d}^{-1}$ と $50,000 \mathrm{~m}^{3} \cdot \mathrm{d}^{-1}$ の規模の試設計の

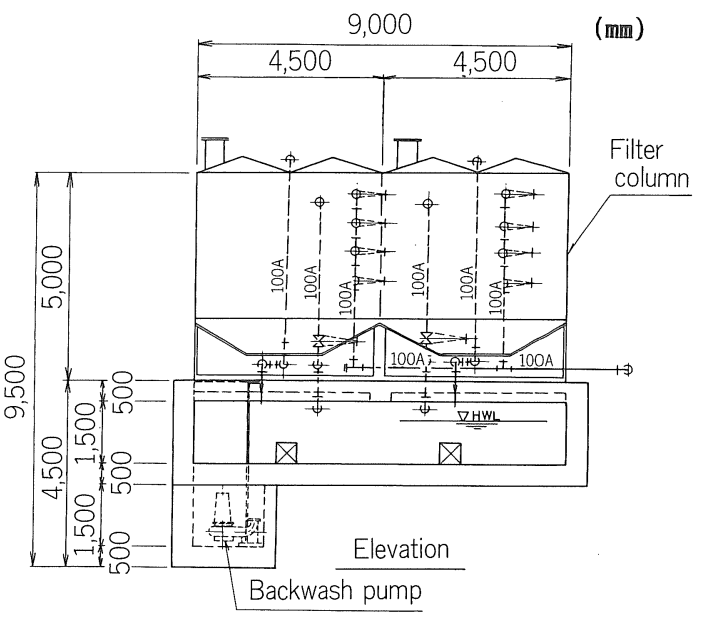

Fig. 14 Outline plan of $5,000 \mathrm{~m}^{3} \cdot \mathrm{d}^{-1}$ plant 
結果, 本沪過工程の所要面積はそれぞれ $90 \mathrm{~m}^{2}, 627 \mathrm{~m}^{2}$ と 従来の最初沈殿池の35～50\%であり，かなりの省面積 化が図れることがわかった。所要電気量は $5,000 \mathrm{~m}^{3}$ 。 $\mathrm{d}^{-1}$ 規模で0.056〜0.078 $\mathrm{kwh} \cdot \mathrm{m}^{-3}$ であることがわかっ た。

\section{謝 辞}

本研究はバイオフォーカス WT プロジェクトの一 環として建設省土木研究所と実施した共同研究の一部 である。

研究の実施にあたり，建設省土木研究所下水道部の 関係各位から，多くの御指導と御教示をいただいたこ とに対し，深く感謝いたします。

（原稿受付 1991年5月21日） （原稿受理 1991年 8 月 5 日）

\section{参 考 文 献}

1) バイオテクノロジーを活用した新排水処理システムの開発 報告書（下水道編）（1991）建設省.

2 ) 小越真佐司 (1990) 下水前処理用の高効率固液分離装置の開
発，土木技術資料，32，56 59 。

3 ) 田代辰夫, 山内愛造（1989）球状高分子による水中のバクテ リアの除去, 平成元年度緎維高分子材料研究所研究発表会資 料, $14 \sim 27$.

$4)$ 下水 2 次処理水の急速沪過設計マニュアル（1982）社日本下 水道協会.

5 ）井出哲夫（1990）水処理工学, 101～152, 技報堂, 東京.

6 ) 合田健（1979）水質工学 (応用編), 32 46, 丸善, 東京.

7 ) 丹保憲仁, 小林三樹 (1982) 高容量沪過池の研究, 水道協会 雑誌, $571 ， 37 \sim 50$.

8 ) 丹保憲仁, 松井佳彦, 岡本裕三 (1984) 高容量沪過池の研究 (II)，水道協会雑誌，598，16～23。

9 ) 小越真佐司（1986）粗沪材を用いた下向流式汇過，第23回下 水道研究発表会講演集, 437 439.

10) Matsumoto, M.R., Galeziewski, G. and Ross, D,S. (1982) Filtration of primary effluent, Journal of Water Pollution Control Federation, 54, 1581 1591.

11) Moreley, D.A. (1979) Mathematical modelling in water and wastewater treatment, 184 216, Applied Science, London.

12）貫上佳則，本多淳裕，西谷道暢（1990）回転汇過筒を用いた 排水の固液分離に関する研究, 水質污濁研究, $13,39 \sim 47$. 


\section{多段土壤層法による脱窒脱リン合併排水処理装置}

若月 利之* 江角比出郎** 小村 修一***

* 島根大学農学部 $* *$ 島根県衛生公害研究所 $* * * *$ カナツ技建

〈水質污濁研究 Vol. 14 No. 10（1991） pp.709 719〉

多段土壤層法とは，通水用土壤層と浄化用土壌層とをレンガ積層パターンで多段に積層させ，污水がこの多 段土壌層を流下する間に浄化させようとするものである。

浄化用土壌層は，マサ土に金属鉄粒とペレット化したジュートを各 5 ～15\%添加したものを，厚さ $7.5 〜 10$ $\mathrm{cm}$ ，幅 $60 \mathrm{~cm}$ ，長さ120〜175cm の単位サイズで用いた。通水用土壌層としては，粒径が $1 〜 5 \mathrm{~mm}$ のゼオライ 卜を $5 \sim 10 \mathrm{~cm}$ の層厚で用いた。この浄化用土壌層と通水用土壌層を各 5 〜 段積層させた。また，多段層の下 の通気管を設置した。

単独浄化槽排水と雑排水の合併排水を処理する実規模の装置を久留米市と松江市に設置して処理性能を 1 〜半年間調査した。調査期間中，負荷量 $100 \sim 800 l \cdot \mathrm{m}^{-2} \cdot \mathrm{d}^{-1}$ で目詰まりは生じなかった。処理水の平均 BOD $5 \mathrm{mg} \cdot l^{-1}$, T-N $5 \mathrm{mg} \cdot l^{-1}$, T-P0.8mg・ $l^{-1}$ であった。通気は処理性能に大きな影響を与えた。本法は有機 物，窒素リン除去能が高く，富栄養化防止に有効な施設となり得ることを認めた。

\section{浮上性沪材を用いた下水の固液分離処理法の研究}

毛利 光男* 丹羽 千明*

* 清水建設株式会社技術研究所シーブルー特別研究グループ

〈水質污濁研究 Vol. 14 No. 10（1991） pp.720～729〉

本研究では，発泡ポリスチレン沪材と多段切り換え原水供給方式を用いた生下水の直接沪過において，高効 率除去に適した沪材径と原水供給管の設置間隔の選定，浮上性沪層の固液分離特性，沪材の耐久性，および分 離懸濁物の沈降濃縮特性等について実験的に検討した。実験の結果，沪材径は $5.5 \mathrm{~mm}$ が適切であり，原水供給 を沪層の閉塞により，順次下の供給管に切り換える本沪過方式は沪過継続時間と SS 捕捉量を大幅に増大する ことがわかった。汇層厚 $3 \mathrm{~m}$ ，汇過速度 $150 \mathrm{~m} ・ \mathrm{~d}^{-1} \sim 220 \mathrm{~m} \cdot \mathrm{d}^{-1}$ ，および 4 段の切り換え沪過の場合， SS 除去 率が $80 \%$ 以上，BOD 除去率が約 $50 \%$ ，沪過継続時間が30時間以上，および洗浄水量比が 2 〜 \%であった。沪 材径は，1.5年間の運転で初期値の約 $80 \%$ まで縮小するがその後はさほど縮小しないことがわかった。 5,000 と $50,000 \mathrm{~m}^{3} \cdot \mathrm{d}^{-1}$ 規模の試設計の結果，本汇過法の所用面積は最初沈殿池の 35 ～ $50 \%$ であり，かなりの省面積化を 図れることがわかった。 